ISSN 0258-7122 (Print), 2408-8293 (Online)

Bangladesh J. Agril. Res. 44(1): 127-138, March 2019

\title{
EFFICACY OF DIFFERENT SUBSTRATES TO FORMULATE Trichoderma harzianum AGAINST SEEDLING DISEASE OF CABBAGE
}

\begin{abstract}
M. I. FARUK ${ }^{1}$
Abstract

Efficacy of three different substrates viz. rice bran, wheat bran, grass pea bran and their combination along with or without Mustard oilcake (MOC) were tested to formulate Trichoderma harzianum based bio-fungicides for the management of seedling disease (Fusarium oxysporum) of cabbage in seedbed. All combinations of substrates were equally suitable for mass culturing and preparing of $T$. harzianum bio-fungicides and all the substrates based $T$. harzianum bio-fungicides were effective in increasing seedling emergence and reducing pre-emergence and post-emergence mortality of cabbage seedling under $F$. oxysporum inoculated seedbed soils. The shoot length, shoot weight, root length and root weight of cabbage seedling were enhanced significantly by the application of different substrates based $T$. harzianum bio-fungicides under $F$. oxysporum inoculated soil under seedbed conditions. The individual (rice bran, wheat bran, grasspea bran) and combination of substrates (rice bran + wheat bran, rice bran + grasspea bran, rice bran + Mustard oilcake, rice bran + wheat bran + MOC and wheat bran + grass pea bran + MOC) were equally suitable to formulate effective $T$. harzianum based bio-fungicides for the management of foot and root rot disease of cabbage seedling in seed bed condition.
\end{abstract}

Keywords: Rice bran, wheat bran, grasspea bran, mustard oilcake, Trichoderma harzianum, Fusarium oxysporum, cabbage.

\section{Introduction}

Availability of quality food and nutrition are the major challenges to achieve healthy and prosperous Bangladesh like other developing countries of the world. Bangladesh is yet to be self-sufficient in quality food and nutrition. In the country vegetables play a vital role in everyday diet to a huge population in general. Among the vegetables, cabbage (Brassica oleracea) is one of the popular herbaceous annual or biennial vegetable that has achieved tremendous popularity over the last century. The crop attacked by several diseases mostly caused by fungi and bacteria leading to severe crop losses. Among the diseases germination failure, seedling mortality, foot and root-rot disease caused by the soil borne pathogen Fusarium oxysporum, is one of the major constraints for seedling

${ }^{1}$ Senior Scientific Officer, Plant Pathology Division, Bangladesh Agricultural Research Institute (BARI), Joydebpur, Gazipur-1701, Bangladesh. 
production of vegetable crops in seedbed (Najar et al., 2011). Control measures like host resistance is not yet become a viable measure. No resistant variety of cabbage has yet been developed and released against this soil borne pathogen $F$. oxysporum in Bangladesh. Soil solarization and organic soil amendment have been found less effective. On the other hand, application of chemical fungicides is expensive and also hazardous to health and environment (Brown and Hendrix, 1980; Punja et. al., 1982). Biological methods, on the other hand can be economical, sustainable and free from residual effects and also consider as a potentially effective alternative method (Kulkarni et al., 2007; Anand and Reddy, 2009). The beneficial microbes are used as biological agents that effectively control soil borne plant pathogens, and about $90 \%$ of such bio-control agents are different strains of T. harzianum, T. virens, T. viride (Elad et al., 1983; Roy, 1989; Benítez et al., 2004). The fungus Trichoderma possesses different mechanisms to combat the targeted pathogen such as mycoparasitism, competition for space and nutrients, secretion of antibiotics and fungal cell wall degrading enzymes for the inhibition of growth and reproduction of phytopathogens (Kubicek et al., 2001; Howell, 2003; Benítez et al., 2004; Harman et al., 2004). In addition, Trichoderma has a stimulatory effect on plant growth (Naseby et al., 2000) as a result of modification of soil conditions. The native bio-control agents usually remain in low population density in most of the agricultural soil, so up- scaling of their density to a higher stability level in soil through artificial inoculation with effective inoculum is necessary for successful management of soil borne pathogens in cabbage seedbed. The major limitation is the lack of appropriate mass culturing techniques and inadequate information on the suitable substrate materials of T. harzianum (Harman et al., 1991). Several research report revealed that $T$. harzianum has been formulated as bio-fungicides in various substrates including wheat bran, rice bran, maize bran, sawdust (Das et al., 1997); rice straw, chickpea bran, grasspea bran, rice course powder, black gram bran (Shamsuzzaman et al., 2003); cow dung, poultry manure, groundnut shell, black ash, coir waste, spent straw from mushroom bed, talc, vermiculite (Rettinassababady and Ramadoss, 2000); and jaggery, groundnut cake, neem cake, niger cake, pongamia (Shamarao et al., 1998). All these substrate materials are available in Bangladesh but their potentialities to use in the formulation of $T$. harzianum bio-fungicide have not yet been studied in the country. Therefore, the present study was undertaken to find out the effective local substrates to formulate the suitable medium for mass culturing of T. harzianum to be used as effective bio-fungicides against $F$. oxysporum causing seedling disease of cabbage under seedbed condition.

\section{Materials and Methods}

Efficacy of three organic substrates viz. rice bran, wheat bran, grasspea bran and their combinations mixed with or without Mustard oilcake (MOC) was 
evaluated to formulate $T$. harzianum based bio-fungicides for the management of foot and root rot disease of cabbage caused by F. oxysporum. The experiment was conducted in seedbed of Plant Pathology Division, Bangladesh Agricultural Research Institute (BARl), Gazipur during three consecutive years from 2011-12 to 2013-14. The seedbed was inoculated with the fungal isolate $F$. oxysporum multiplied on the barley grains @ $100 \mathrm{~g} / \mathrm{m}^{2}$ soil. The pathogen was allowed to colonize the soil in seedbed for 10 days. A pure culture of $T$. harzianum (TM7) isolated from the native soil was grown in potato dextrose agar (PDA) medium which was used as inocula for preparation of bio-fungicides. The treatments substrate in the experiment were $\mathrm{T}_{1}=$ Rice bran, $\mathrm{T}_{2}=$ Wheat bran, $\mathrm{T}_{3}=$ Grasspea bran, $\mathrm{T}_{4}=$ Rice bran + Wheat bran (1:1), $\mathrm{T}_{5}=$ Rice bran + Grasspea bran $(1: 1), \mathrm{T}_{6}=$ Rice bran + Mustard oilcake (1:1), $\mathrm{T}_{7}=$ Rice bran + Wheat bran + MOC $(1: 1: 1), \mathrm{T}_{8}=$ Rice bran + Grasspea bran + MOC (1:1:1), $\mathrm{T}_{9}=$ Wheat bran + Grasspea bran + MOC (1:1:1), $\mathrm{T}_{10}=$ Rice bran + Wheat bran + Grasspea bran + MOC $(1: 1: 1: 1)$, $\mathrm{T}_{11}=$ Seed treatment with Provax and $\mathrm{T}_{12}=$ Control. According to the treatment combinations $600 \mathrm{~g}$ of individual or combination of substrate materials were taken separately in $1000 \mathrm{ml}$ Erlenmeyer flask. The flask with substrate materials were sterilized in an autoclave at $121^{\circ} \mathrm{C}$ for 15 minutes and cooled down to make it ready for inoculation. The sterilized substrate was inoculated individually with $5 \mathrm{~mm}$ diameter mycelia disc of five-day old culture of $T$. harzianum grown on PDA and then incubated at room temperature $\left(25 \pm 2{ }^{\circ} \mathrm{C}\right)$ for 15 days. After incubation the colonized substrates were removed from the flasks, air dried and finally preserved in refrigerator at $10{ }^{\circ} \mathrm{C}$. The inoculum of $T$. harzianum, colonized on different substrates, were incorporated to the previously $F$. oxysporum inoculated seedbed soils @ $100 \mathrm{~g} / \mathrm{m}^{2}$ soil and kept for 7 days maintaining proper soil moisture to establish $T$. harzianum in the soils. The control bed did not receive any colonized substrate of T. harzianum except the inoculum of $F$. oxysporum. The seeds of cabbage variety Atlas were sown in the seedbed @ 200 seeds per treatment. The initial germination in blotter test of the seeds was 99\%. The percent emergence of the seedling was calculated on the basis of initial germination status of the seeds. The experiment was laid out in completely randomized design (CRD) with four replications. Proper weeding, irrigation and intercultural operations were done to raise cabbage seedlings in the seedbed. Data were collected on seedling emergence after 15 days of seed sowing. Similarly seedling mortality was recorded at an interval of 7 days starting from seedling emergence and it was continued up to 35 days of seedling age. The height and weight of shoot and length and weight of root of tomato seedlings were recorded at 35 days of seedling age. The percent data were converted into arcsine transformation values before statistical analysis. Data were analyzed statistically by using the MSTATC program. The treatment effects were compared by applying the least significant different (LSD) test at $\mathrm{P}=0.05$ level. 


\section{Results and Discussion}

\section{a) Seedling emergence and pre-emergence mortality}

Every year, the seedling emergence of cabbage was significantly increased over control in the $F$. oxysporum inoculated seedbed due to $T$ harzianum bio-fungicides. Under control treatment the emergence was 49.33, 64.00 and $66.00 \%$ in $1^{\text {st }}, 2^{\text {nd }}$ and $3^{\text {rd }}$ year, respectively. The seedling emergence ranged from $58.00-$

$67.00,80.33-86.67$ and $79.00-91.00 \%$ due to treatment of seedbed soil with the bio-fungicides in $1^{\text {st }}, 2^{\text {nd }}$ and $3^{\text {rd }}$ year, respectively. Seedling emergence under various treatments with the bio-fungicides was statistically similar (Table 1).

On the contrary, the pre-emergence seedling mortality of cabbage under control was $50.67,36.00$ and $34.00 \%$ in $1^{\text {st }}, 2^{\text {nd }}$ and $3^{\text {rd }}$ year, respectively. The corresponding mortality under treatment of seedbed soils with the bio-fungicides was 33.00-42.00\% in first year, 13.33-19.67\% in second year and $09.00-21.00 \%$ in third year. It was reduced to $17.11-34.87,45.36-62.97$ and $38.23-73.53 \%$ in first, second and third year, respectively due to treatments of seedbed soils with various bio-fungicides (Table 1). However, efficacy of all bio-fungicides was more or less similar.

\section{b) Post-emergence mortality}

Post-emergence mortality of cabbage in $F$. oxysporum inoculated seedbed soil was

$21.33,33.67$ and $24.67 \%$ under treatment control in $1^{\text {st }}, 2^{\text {nd }}$ and $3^{\text {rd }}$ year of study, respectively. The substrates based $T$. harzianum bio-fungicides reduced the disease incidence from 64.04-73.42, 60.41-66.35 and 60.80-72.96\% in $1^{\text {st }}, 2^{\text {nd }}$ and $3^{\text {rd }}$ year, respectively compared to untreated control. Efficacy of all biofungicides to reduce the disease incidence was statistically similar (Table 2).

\section{c) Shoot growth}

Shoot length and shoot weight of cabbage seedlings were increased significantly by different substrates based T. harzianum bio-fungicides over Provax and untreated control in the $F$. oxysporum inoculated seed bed soil (Table 3 ). Under control seedbed, shoot length was $13.03 \mathrm{~cm}$ in first year, $4.90 \mathrm{~cm}$ in second year and $10.87 \mathrm{~cm}$ in third year. Treatment of seedbed soils with $T$ harzianum based bio-fungicides resulted increase in shoot length ranging by 17.07-18.13, 8.3010.13 and $16.33-22.07 \mathrm{~cm}$ in $1^{\text {st }}, 2^{\text {nd }}$ and $3^{\text {rd }}$ year, respectively. The shoot weight under control treatment was 3.75, 3.97 and $6.57 \mathrm{~g} \mathrm{plant}^{-1}$ in first, second and third year, respectively. Treatments of seedbed soils by $T$. harzianum based biofungicides increased the shoot weight ranging 5.53- 5.81, 7.11-8.53 and 8.88$12.40 \mathrm{~g} \mathrm{plant}^{-1}$ in $1^{\text {st }}, 2^{\text {nd }}$ and $3^{\text {rd }}$ year, respectively. Effect of all bio-fungicides treatments on shoot growth was more or less similar (Table 3 ). 


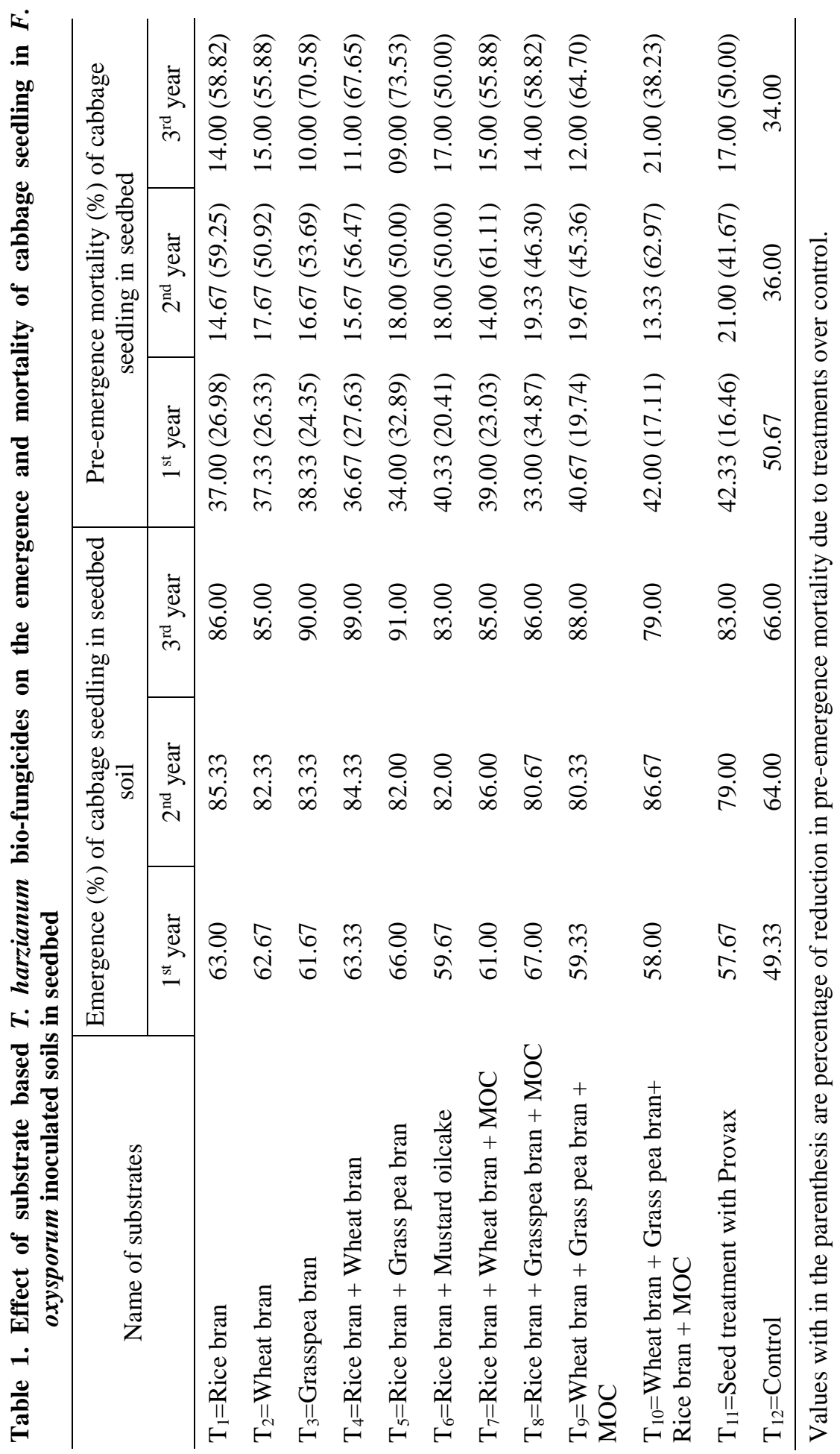




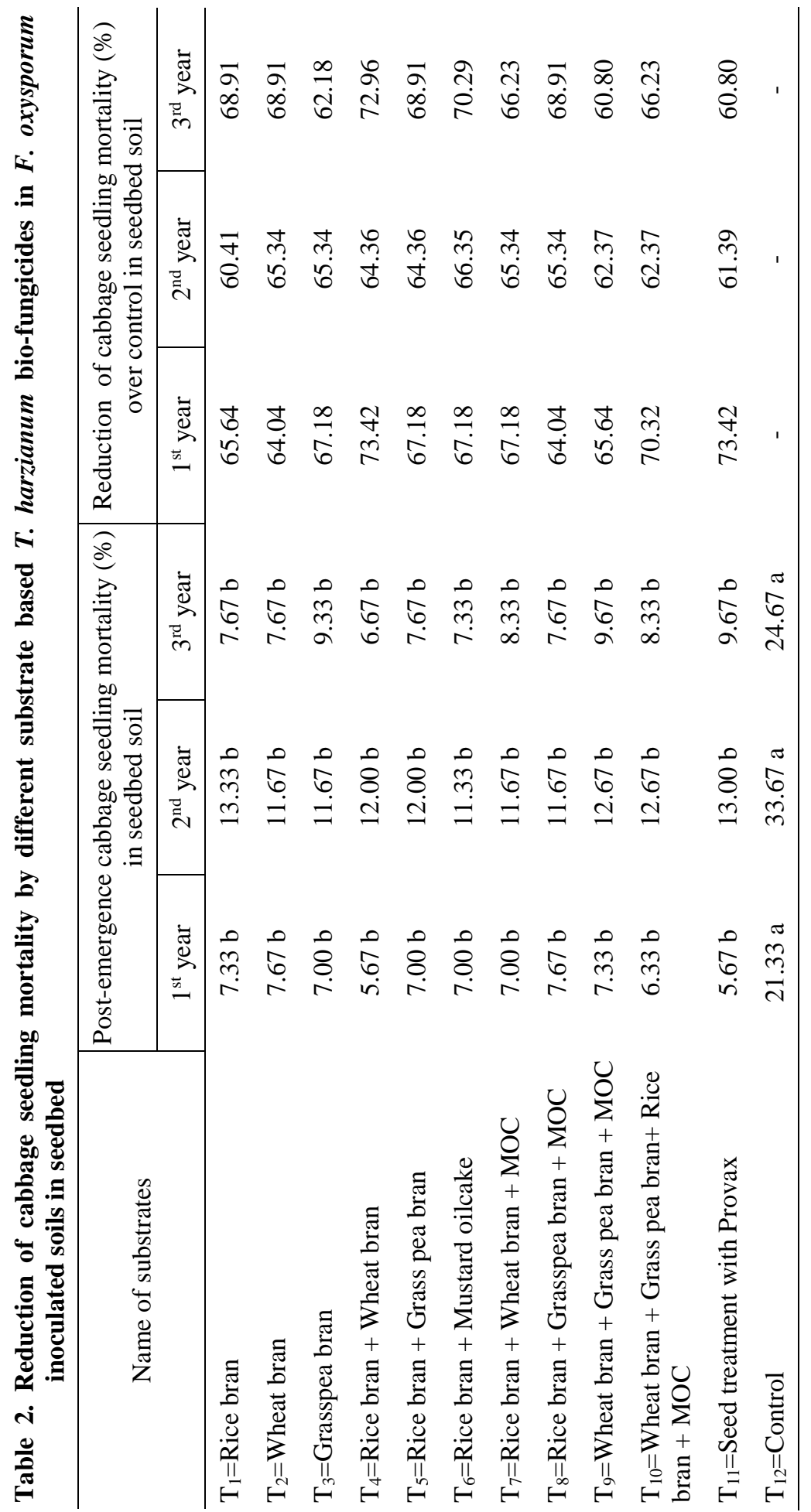




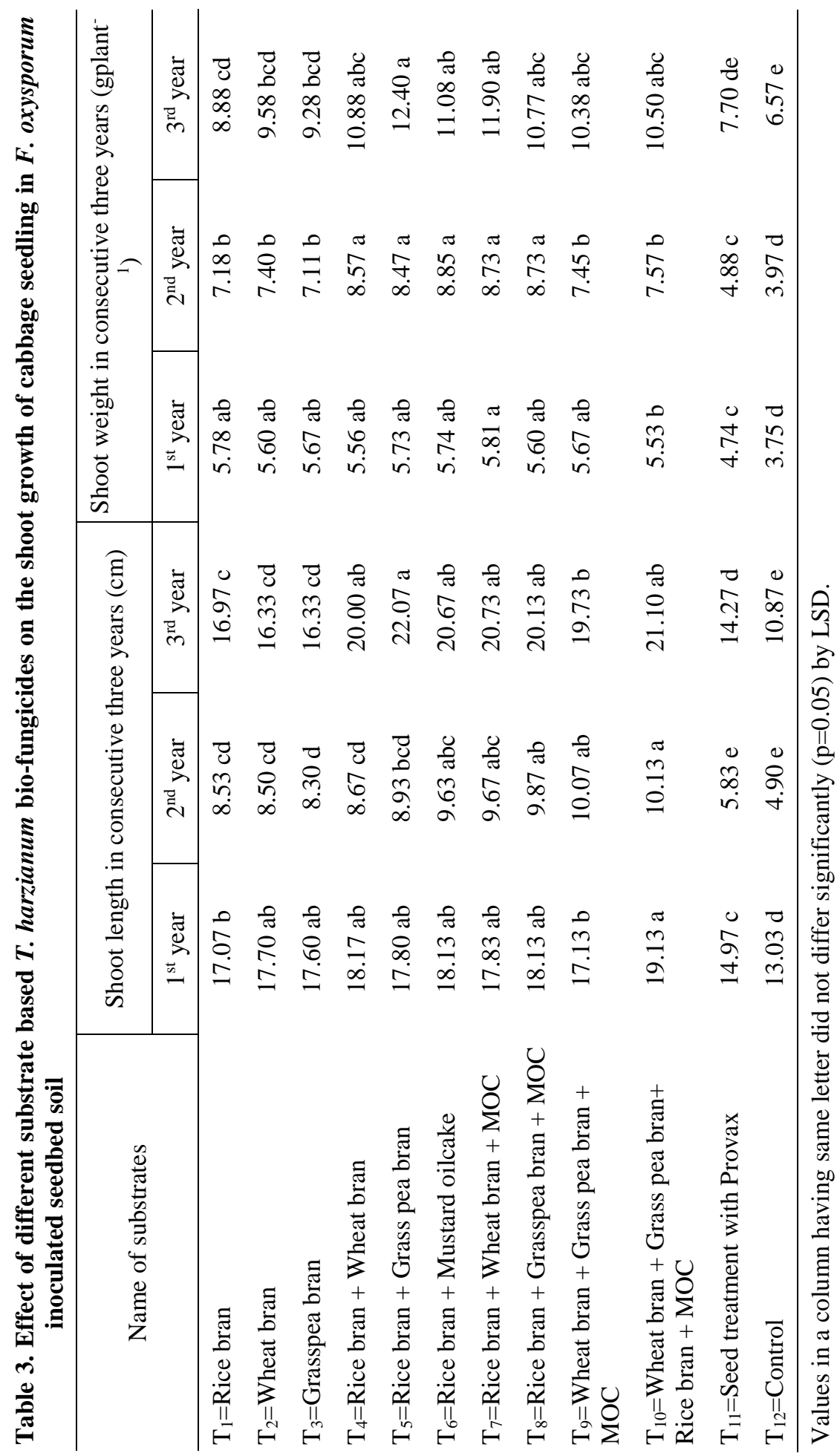




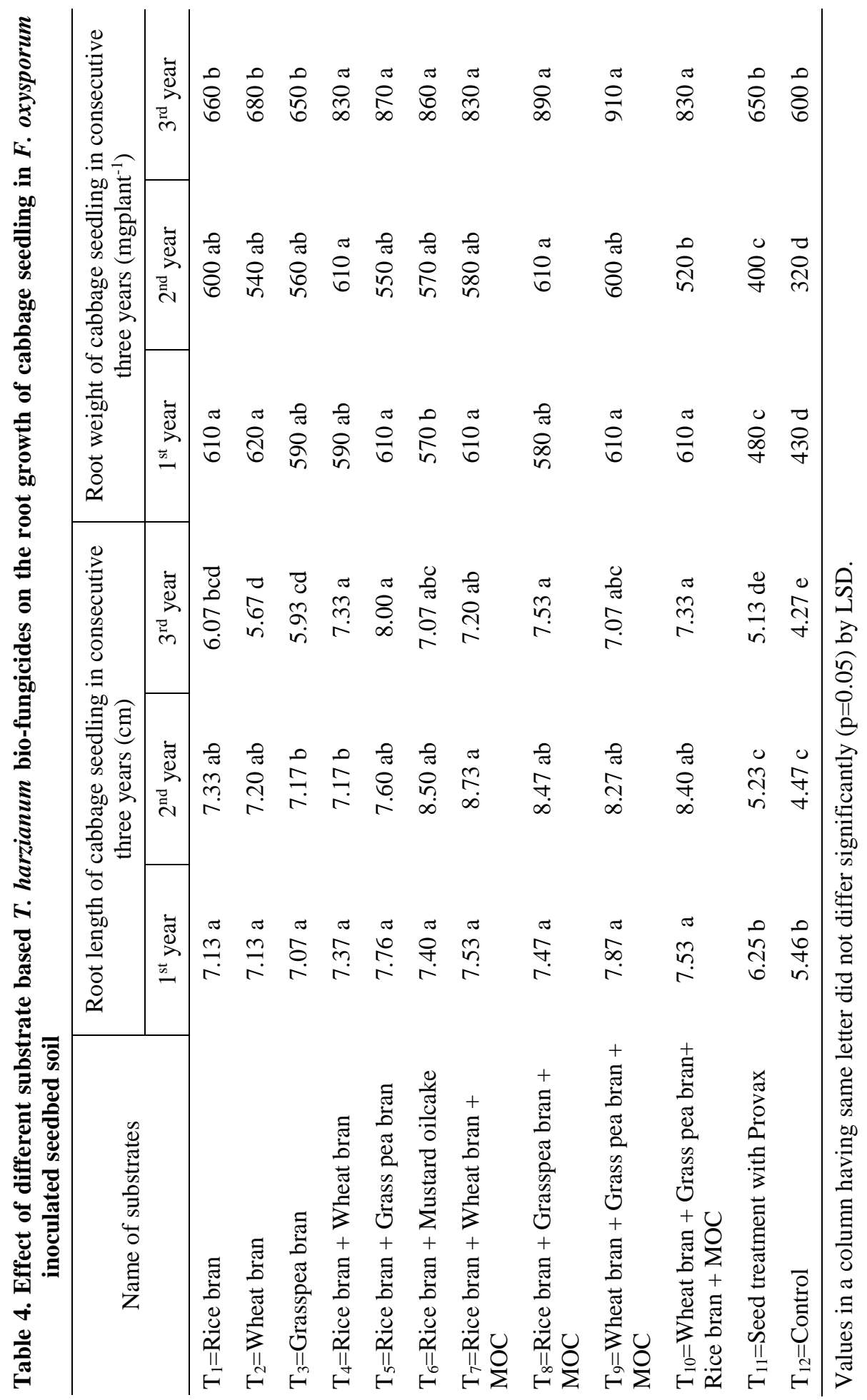




\section{d) Root growth}

Every year, the root length of cabbage seedling was significantly lower in nontreated seedbed (control) compared to bio-fungicide and Provax treated beds. The root length of cabbage seedlings during consecutive three years ranged from 7.077.87, 7.17-8.37 and 5.67-8.00 cm under different treatments and 5.46, 4.47 and $4.27 \mathrm{~cm}$ in control seedbeds, respectively (Table 4).

The root weights were also higher having 0.58-0.62, 0.52-0.61 and 0.65-0.91 g plant ${ }^{-1}$, in the $1^{\text {st }}, 2^{\text {nd }}$ and $3^{\text {rd }}$ year respectively in the seedbed treated with $T$. harzianum based bio-fungicides and the lowest root weight $0.43,0.32$ and $0.60 \mathrm{~g}$ plant $^{-1}$ in $1^{\text {st }}, 2^{\text {nd }}$ and $3^{\text {rd }}$ year, respectively in the control seedbeds (Table 4). The root weight was significantly higher compared to seedbeds received neither biofungicide nor Provax. Effect of bio-fungicide treatments on root growth was more or less similar (Table 4).

Seed treatment with Provax was also effective to reduce the incidence of foot and root rot disease and to increase shoot and root growth of cabbage seedlings over control in seedbed soil infested with $F$. oxysporum. However, its efficacy was lower compared to all bio-fungicides (Tables 1-4).

Results of the present experiment revealed that biological control agent $T$. harzianum multiplied on different substrates materials viz. rice bran, wheat bran, grasspea bran used alone or in different combinations mixed with or without MOC were effective against foot and root disease of cabbage caused by $F$. oxysporum under seedbed condition. The bio-fungicides achieved satisfactory increase in seed germination, decrease pre- and post-emergence seedling mortality and also enhance growth of cabbage seedling. Similar findings were reported by other researchers (Bentez et al., 2004; Mausam et al., 2007; Prasad and Anes, 2008; Mukhtar, 2008; John et al., 2010). The well-known antagonistic fungus Trichoderma spp. could directly parasitize a diversity of fungi as they were capable of detecting other fungi in the soil and destroyed other plant pathogenic fungi through expression of cell wall degrading enzymes, mostly chitinases, glucanases and proteases (Harman et al., 2004). The fungus $T$. harzianum prevailing in the soil was being used in many crops, like lettuce, tomato, onion, cotton, grapes, peas, apples, sweet corn and carrots to control various diseases caused by Phytophthora, Pythium, Sclerotinia, Botrytis, Rhizoctonia and Fusarium (Benítez et al., 2004; Mausam et al., 2007). These findings were in accordance with the observation of the present study where soil was treated with different substrates based $T$. harzianum bio-fungicides that enhanced the growth of cabbage seedling in $F$. oxysporum inoculated seedbed soils though the degree of shoot and root growth varied among the treatments. Harman (2006) and Manju and Mall (2008) also reported positive role of Trichoderma species in increasing plant growth and productivity. In present experiment there was significant increase in emergence, shoot and root length 
and also shoot and root weights of tomato seedling due to $T$. harzianum biofungicides which was supported by the findings of many investigators (Prasad and Anes, 2008; Mishra and Sinha, 2000; Chaur-Tsuen and Chien-Yih, 2002). It was reported that Trichoderma isolates possesses the ability to compete for key exudates from seeds that stimulate germination of propagules of plant pathogenic fungi in the soil as they compete with microorganisms for nutrient and space. The three well known mechanisms associated with pathogen control by Trichoderma were competition for nutrients, antibiosis, and myco-parasitism (Chet, 1987). It was noticed by Tjamos et al. (1992) that $T$. harzianum controls $F$. oxysporum by competing for both rhizosphere colonization and nutrients. The study confirmrd the reports of other researchers regarding the role of $T$. harzianum to enhance seed germination and root and shoot growth of seedlings (Dubey et al., 2007) as well as increasing the frequency of healthy plants (Rojo et al., 2007). Shoresh et al. (2005) stated that Trichoderma spp. were effective bio-control agents for a number of soil borne plant pathogens and induced a potentate state in the plant enabling it to be more resistant to subsequent pathogen infection.

\section{Acknowledgement}

The authors thankfully acknowledged BAS-USDA who provided financial support and Bangladesh Agricultural Research Institute, Gazipur for extending necessary logistic support for smooth running of this research. Special thanks to Dr. M. A. Rahman, former Chief Scientific Officer, Plant Pathology Division, BARI for his fruitful counsel and directives. Thanks also go to the Scientific Assistant Mr. Md. Abdur Razzak and Mr. Zamil Akter for their sincere assistance in this research work.

\section{References}

Anand, S. and J. Reddy. 2009. Biocontrol potential of Trichoderma sp. against plant pathogens, Int. J. of Agric. Sci. 1(2): Pp. 30-39.

Benítez, T., A. M. Rincón, M. C. Limón and A. C. Codón. 2004. Biocontrol mechanisms of Trichoderma strains. Int. Microbiol. 7: 249-260.

Brown, E. A. and F.F. Hendrix. 1980. Distribution and control of S. rolfsii on apple. Plant Dis. 64: 205-206.

Chaur-Tsuen, L. and L.Chien-Yih. 2002. Screening strains of Trichoderma spp. for plant growth enhancement in Taiwan. Plant Pathol. Bull. 11: 215-220.

Chet, I. 1987. Trichoderma -application, mode of action and potential as a biocontrol agent of soil borne plant pathogenic fungi. In: Chet, I. (ed.), Innovative approaches to plant disease control. Wiley, New York, pp 137-160.

Das, B. C., S.K. Roy and L.C. Bora. 1997. Mass multiplication of Trichoderma species on different media. J. Agril. Sci. Society of North East India. 10(1): 95-100.

Dubey, S. C., M. Suresha and B. Singha. 2007. Evaluation of Trichoderma species against Fusarium oxysporum f. sp. ciceris for integrated management of chickpea wilt. Biological Control. 40: 118-127. 
Elad, Y., I. Chet and J. Katan. 1983. Trichoderma harzianum: A biocontrol agent effective against Sclerotium rolfsii and Rhizoctonia solani. Phytopathol. 70: 119-121.

Harman, G. E. 2006. Overview of mechanisms and uses of Trichoderma spp. Phytopathol. 96: 190-194.

Harman, G.E., C.R. Howell, A. Viterbo, I. Chet and M. Lorito. 2004. Trichoderma species opportunistic, avirulent plant symbionts. Nature Reviews Microbiol. 2(1): 43-56.

Harman, G.E., A.G. Taylor and D. Hornby. 1991. Development of an effective biological seed treatment system. Biological Control of Soil-borne Plant Pathogens. pp 415-426.

Howell, C. R. 2003. Mechanisms employed by Trichoderma species in the biological control of plant diseases: The history and evolution of current concepts. Plant Dis., 87: 4-10.

John, R. P., R. D. Tyagi, D. Prévost, S. K. Brar, S. Pouleur and R. Y. Surampalli. 2010. Mycoparasitic Trichoderma viride as a biocontrol agent against Fusarium oxysporum f. sp. adzuki and Pythium arrhenomanes and as a growth promoter of soybean. Crop Prot. 29(12): 1452-1459.

Kubicek, C. P., R. L. Mach, C. K. Peterbauer and M. Lorito. 2001. Trichoderma: from genes to biocontrol. J. of Plant Pathol. 83(2): 11-23.

Kulkarni, M., R. Chaudhari and A. Chaudhari. 2007. Novel tensio-active microbial compounds for biocontrol applicatins. In: General Concepts in Integrated Pest and Disease Management (eds. A. Ciancio and K.G. Mukerji). Springer: 295-304.

Manju, S. and T. P. Mall. 2008. Efficacy of Trichoderma species on Phytopthora dresceleri f.sp. cajani of Pigeon pea. Ann. Plant Prot. Sci. 16:162-164.

Mausam V., K. B. Satinder, R.D. Tyagi, R.Y. Surampalli and J. R. Valero. 2007. Antagonistic fungi, Trichoderma spp.: Panoply of biological control. Biochemical Engineering J. 37: 1-20.

Mishra, D. S. and A. P. Sinha. 2000. Plant growth promoting activity of some fungal and bacteria agents on rice seed germination and seedling growth. Tropical Agric. 77:188-191.

Mukhtar, I. 2008. Influence of Trichoderma species on seed germination in okra. Mycopath. 6(1\&2): 47-50.

Najar, A. G., A. Anwar, L. Masoodi and M. S. Khar. 2011. Evaluation of native biocontrol agents against Fusarium solani f. sp. melongenae causing wilt disease of brinjal in Kashmir. J. Phythol. 3: 31-34.

Naseby, D.C., J.A. Pascual and J.M. Lynch. 2000. Effect of biocontrol strains of Trichoderma on plant growth, Pythium ultimum populations, soil microbial communities and soil enzyme activities. J. App. Microbiol. 88: 161-169.

Prasad, D. and K. M. Anes. 2008. Effect of metabolites of Trichoderma harzianum and T. viride on plant growth and Meloidogyne incognita on okra. Ann. Plant Prot. Sci. 16:461-465.

Punja, Z. K., R. G. Grogan and T. Unruh. 1982. Comparative control of S. rolfsii on golf grass in Northern California with fungicides, inorganic salt and Trichoderma spp. Plant Dis. 66: $1125-1128$. 
Rettinassabababy, C. and N. Ramadoss. 2000. Effect of different substrates on the growth and sporulation of Trichoderma viride native isolates. Agril. Sci. Digest. 20(3): 150-152.

Rojo, F. G., M. M. Reynosoa, M. Fereza, S.N. Chulze and A. M. Torres. 2007. Biological control by Trichoderma species of Fusarium solani causing peanut brown root rot under field conditions. Crop Prot. 26:549-555.

Roy, S. J., B. S. Das and L.C. Bora. 1989. Non pestcidal management of damping-off of cabbage caused by Rhizoctonia solani Kuehn. J. Agril. Sci. Society of North East India. 11(2): 127-130.

Shamarao, J., A.L. Siddaramaidah, H. Narayanaswamy and S. Jahagirdar. 1998. Screening of substrates of mass multiplication of Trichoderma viride. Karnataka J. Agril. Sci. 11(1): 233-236.

Shamsuzzaman, S. M. A. Islam and I. Hossain. 2003. Trichoderma culture and germination of sweet gourd seed. Bangladesh J. Seed Sci. and Tech. 7(1 \& 2): 91-95.

Shoresh, M., I. Yedidia and I. Chet. 2005. Involvement of Jasmonic Acid/Ethylene Signaling Pathway in the Systemic Resistance Induced in Cucumber by Trichoderma asperellum $\mathrm{T}_{203}$. Phytopathol. 95(1): 76-84.

Tjamos, E. C., G. C. Papavizas and R. J. Cook, (eds) 1992. Biological control of plant diseases. Progress and challenges for the future. Plenum Press, New York. 462 P. 